\title{
ASBESTOS-CEMENT PIPELINE EXPERIENCE \\ AT THE \\ RAFT RIVER GEOTHERMAL PROJECT
}

April 1977

EG\&G Idaho, Inc.

IDAHO NATIONAL ENGINEERING LABORATORY

ENERGY RESEARCH AND DEVELOPMENT ADMINISTRATION

IDAHO OPERATIONS OFFICE UNDER CONTRACT EY-76-C-07-1570

\section{MASTER}

'TRIBUTION DE IHIS DOCUMENT IS UNLIMITEQ 


\section{DISCLAIMER}

This report was prepared as an account of work sponsored by an agency of the United States Government. Neither the United States Government nor any agency Thereof, nor any of their employees, makes any warranty, express or implied, or assumes any legal liability or responsibility for the accuracy, completeness, or usefulness of any information, apparatus, product, or process disclosed, or represents that its use would not infringe privately owned rights. Reference herein to any specific commercial product, process, or service by trade name, trademark, manufacturer, or otherwise does not necessarily constitute or imply its endorsement, recommendation, or favoring by the United States Government or any agency thereof. The views and opinions of authors expressed herein do not necessarily state or reflect those of the United States Government or any agency thereof. 


\section{DISCLAIMER}

Portions of this document may be illegible in electronic image products. Images are produced from the best available original document. 
Printed in the United States of America

Available from

National Technical Information Service

U.S. Department of Commerce

5285 Port Royal Road

Springfield, Virginia 22161

Price: Printed Copy $\$ 4.00$; Microfiche $\$ 3.00$

\section{NOTICE}

This report was prepared as an account of work sponsored by the United States Government. Neither the United States nor the Energy Research and Development Administration, nor any of their employees, nor any of their contractors, subcontractors, or their employees, makes any warranty, express or implied, or assumes any legal liability or responsibility for the accuracy, completeness or usefulness of any information, apparatus, product or process disclosed, or represents that its use would not infringe privately owned rights. 


\section{TREE-1114 \\ ASBESTOS-CEMENT PIPELINE EXPERIENCE \\ AT THE \\ RAFT RIVER GEOTHERMAL PROJECT}
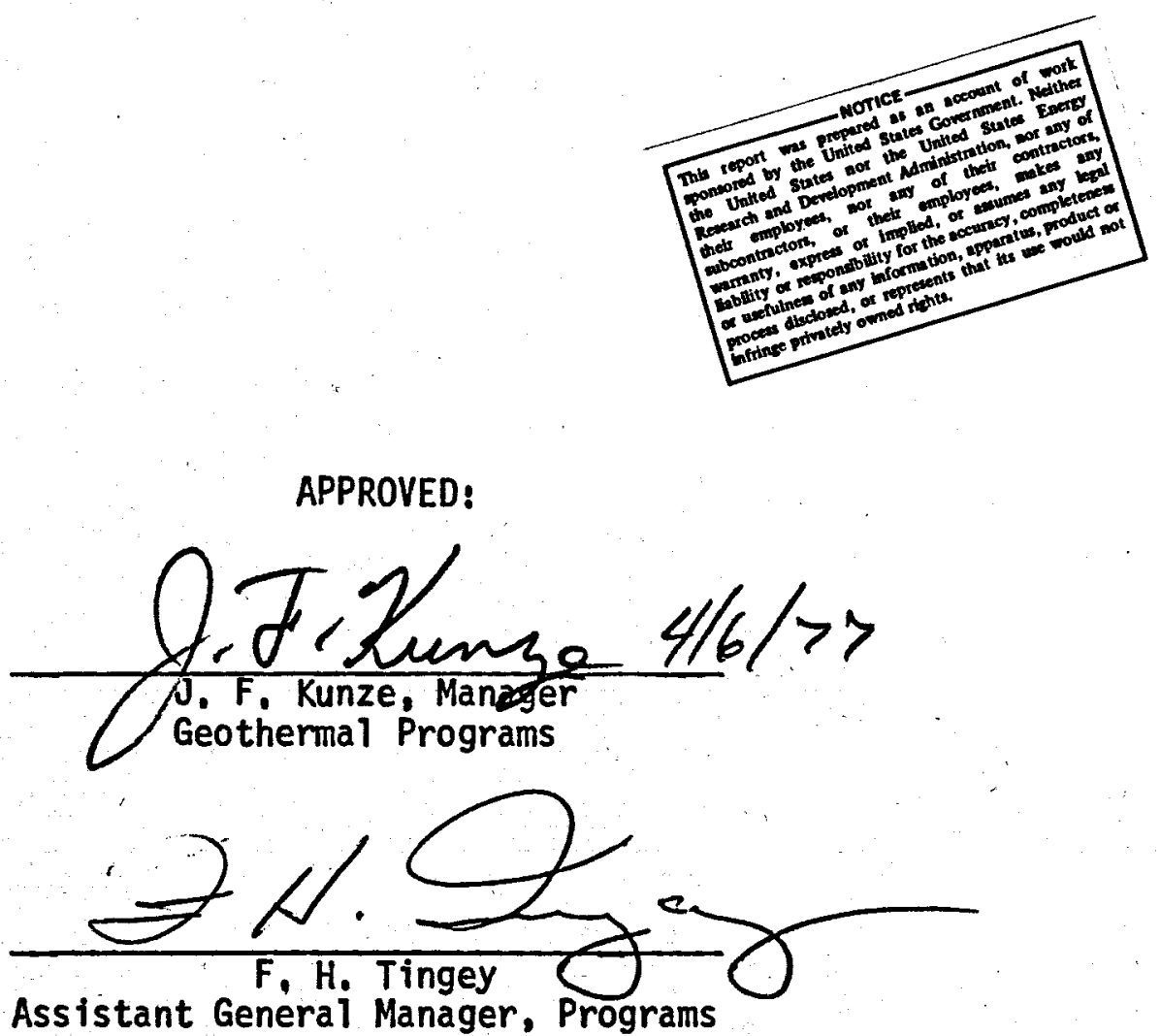


\title{
ASBESTOS-CEMENT PIPELINE EXPERIENCE
}

\section{AT THE}

RAFT RIVER GEOTHERMAL PROJECT

L. G. Miller

J. F. Kunze

R, D. Sanders

\author{
Date Published - April 1977 \\ Prepared for the
}

ENERGY RESEARCH AND DEVELOPMENT ADMINISTRATION

DIVISION OF GEOTHERMAL ENERGY AND IDAHO OPERATIONS OFFICE Under Contract No, EY-76-C-07-1570 
The first buried asbestos-cement ("Transite") pipel ine used in high temperature (approximately $300^{\circ} \mathrm{F}$ ) service for transport of geothermal fluids was installed in the fal1 of 1975, and has seen 1-1/2 years of service. The line is $4000 \mathrm{ft}$ long, between the deep geothermal wells No. 1 and No. 2, in the Raft River Valley of Idaho. The experience in using this pipeline has been satisfactory, and methods have been developed for minimizing the thermal expansion/thermal shock breakage problems. Recommendations on improved design and construction practices for future pipelines are given. The substantially reduced cost (factor of 2) of an asbestos-cement pipel ine compared to the conventional steel pipeline, plus the esthetically desirable effect of a buried pipeline dictate adoption of this type as standard practice for moderate temperature geothermal developments. The Raft River Geothermal Project intends to connect all future wells with pipelines of asbestos-cement, insulated with 1 to 2 -inches of urethane, and buried between 2 and $3 \mathrm{ft}$. Total cost will be approximately $\$ 110,000 / \mathrm{mile}$ for 10 -inch diameter pipe, $\$ 125,000 / \mathrm{mile}$ for 12-inch diameter.

\section{ACKNOWLEDGEMENTS}

The authors wish to recognize the assistance of $J, W_{\text {, Neitzel and }}$ $N$. K. Rogers in the design of the pipelines, and of D. H, Suckling in the operation and documentation of the operating experience. 
CONTENTS

ABSTRACT ............................. i i

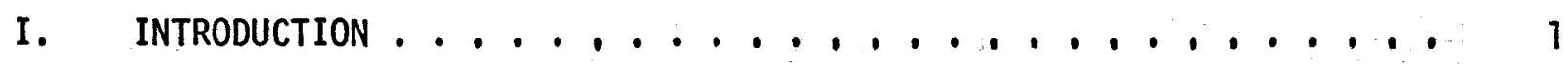

II. JUSTIFICATION FOR USE OF ASBESTOS CEMENT .......... 1

III. DESIGN OF FIRST PIPELINE ............... 3

IV. PIPELINE INSTALlation AND INSPECTION .......... 5

v. PIPELINE OPERATION .................. 5

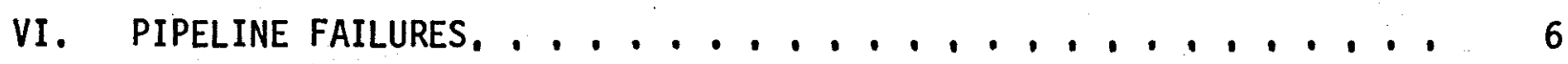

VII. RECOMMENDATIONS FOR FOLLOW-ON PIPELINES, . . . . . . . . 11

VIII. HEAT LOSS FOR BURIED TRANSITE PIPELINE . . . . . . . . 12

IX. CONCLUSIONS, ..................... 16

\section{APPENDICES}

A. PiPeline failures (difficulties) ............. A-1

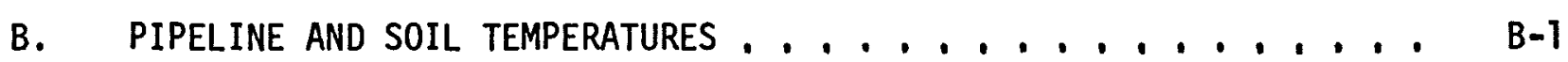




\section{INTRODUCTION}

Asbestos-cement (*Transite) pipe was installed at Raft River between well sites No, 1 and No. 2 for the purpose of transferring water from site No. 1 well and test trailers to site No. 2 for either reinjection into RRGE-2 well or into the site No, 2 reserve pit. The pipeline was designed to take the $300^{\circ} \mathrm{F}$ water at $150 \mathrm{psi}$ over a period of time for the present testing program, and later, the power plant. A number of unexpected line failures occurred which were readily corrected. All but one failure can be attributed to design deficiencies and thermal shock. Cause of one of the failures is unknown, but most likely due to thermal shock. Figure 1 shows the well locations, the existing pipeline between wells No. 1 and No. 2, and the planned two new pipelines.

\section{JUSTIFICATION FOR USE OF ASBESTOS-CEMENT}

Transite pipe was selected over steel or other types of pipe for cost, corrosion, expansion, lower friction loss, etc, Cost estimates indicated that Iransite pipe can be purchased and installed at 55\% of comparable steel pipeline. Reasons for cost reduction can be attributed to: 1) Transite being assembled much faster than welded joint steel pipe; 2) the expansion of each pipe section can be absorbed in each coupling, therefore requiring no large expansion loops; 3) the cost of Transite pipe being less than steel pipe. Pressure drop is much less in the smooth surface Transite than in Standard Schedule 40 steel pipe by a ratio of approximately 0.54 to 1,0 , thus benefiting throughout its lifetime in reduced pumping costs, Ten-inch Transite pipe carrying $1000 \mathrm{gpm}$ experiences a pressure drop of $6.2 \mathrm{psi} / \mathrm{mile}$; a steel pipe $11.5 \mathrm{psi} / \mathrm{mile}$, Corrosion of the steel pipe over a period of years would generally cause this pressure drop ratio to become even larger. This reduced frictional loss in many cases allows the use of smaller Transite pipe, further reducing the cost.

* Registered TN of Johns-Manville Company, 


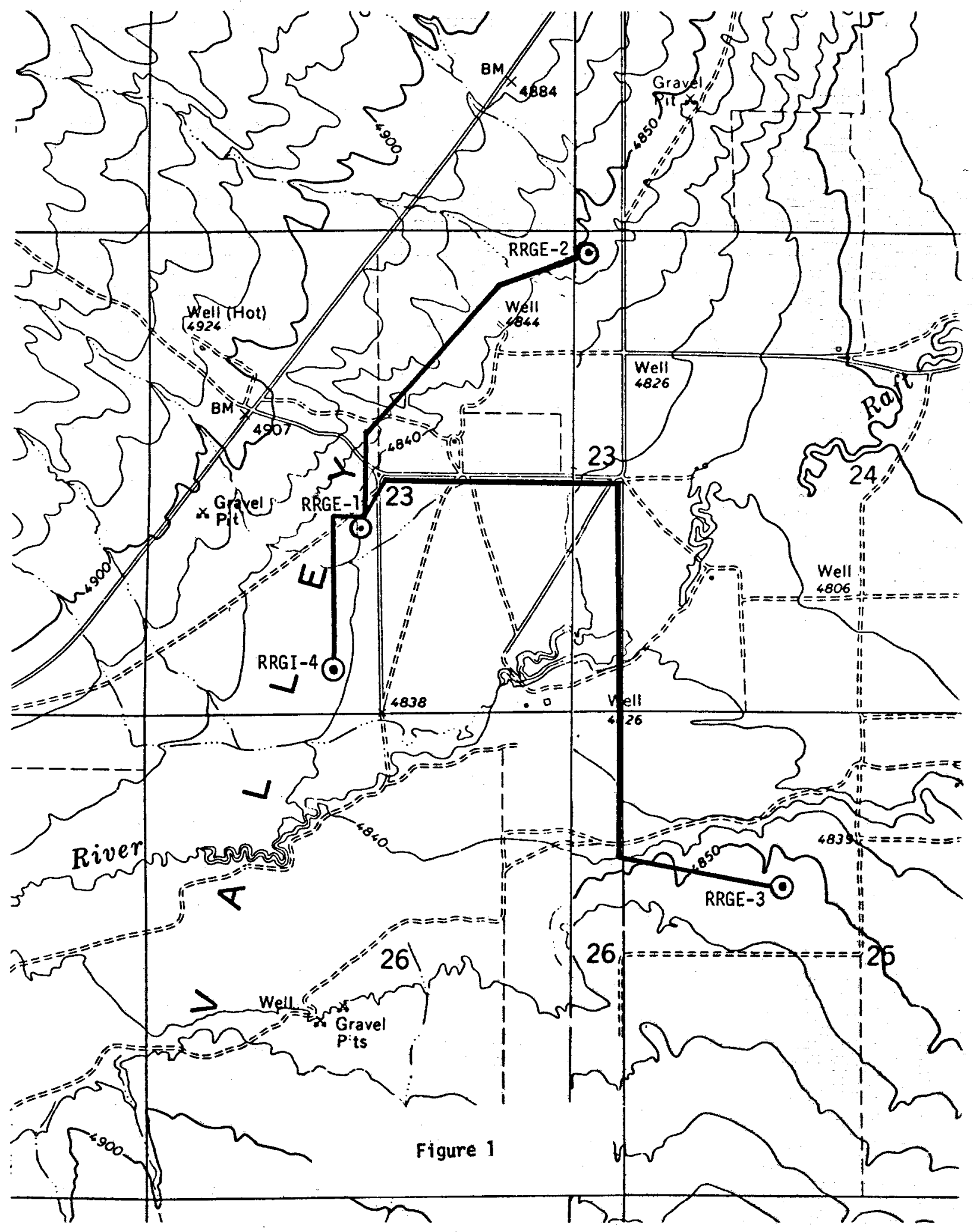




\section{DESIGN OF FIRST PIPELINE}

The first Transite line, approximately $4000 \mathrm{ft}$ long, was laid on a slope so that it could be drained, at several points. The terrain was rolling hills, requiring some pipe to be buried up to $20 \mathrm{ft}$ deep. Trench specifications required the pipe bedding material to be replaced only when encountering gravel containing rock greater than l-inch. Pipe sections were to be supported full length with bell holes*. under each pipe hub. The hubs and pipe were then backfilled and compacted to 4 -inches above the pipe after pressure testing. All backfill was to be free from trash and organic matter.

This pipel ine was insulated only by the surrounding earth, and a $5 \mathrm{ft}$ minimum depth was specified. At the time it was constructed, INEL engineers were unable to identify a suitable insulation material (which has since been done). For this reason high earth removal and backfill costs, plus costs of shoring up the walls for safety, were incurred, Such deep burial is not recommended for future pipelines, but instead insulation with 1 to 2-inches of polyurethane sprayed in place.

Coupling gasket (seal ring) material was a special heat resistant elastamer, EPDM (Ethylene-Propylene Terpolymer). The 1977 Materials engineering Materials Selector lists a $350^{\circ} \mathrm{F}$ continuous service temperature for this compound. Figure 2 shows the gasket installed in a coupling.

Bell-shaped holes dug in the trench under each coupling to make sure support is on pipe section only. It allows inspection of joints during leak testing. 


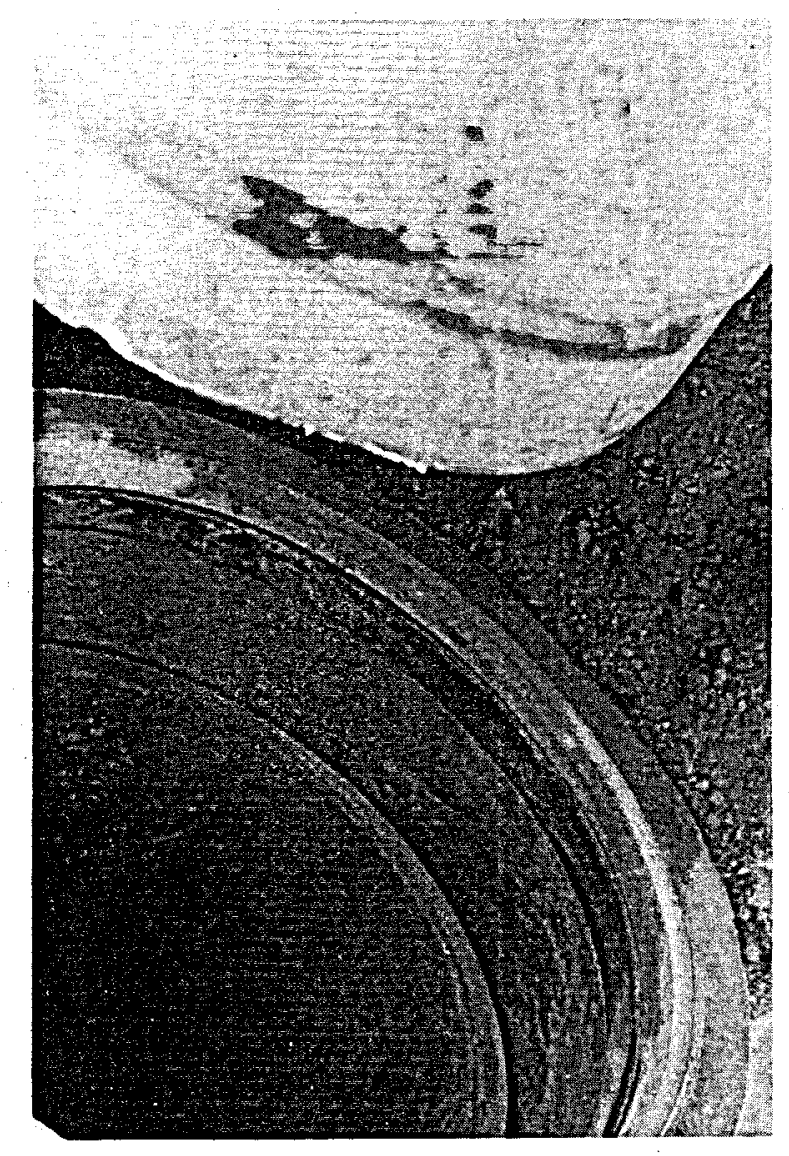

Fig. 2 View of coupling gasket between pipe sections 


\section{PIPELINE INSTALLATION AND INSPECTION}

Only two contractors submitted bids on the installation. The lower bidder was not selected because of his small operation, capability, and inexperience. Inspection during installation was intermittent with an inspector on site only a few hours per day. Only later did inspection show up construction short cuts when sagebrush was found in the backfill near the Transite line, Pressure testing of the line indicated very few gasket leaks.

\section{PIPELINE OPERATION}

The pipeline was used in two ways, one to transfer the hot geothermal water from test trailer and well pump tests, and the second to transfer cool water from the site No. 1 cooling pond. This forces the line to transfer hot and cool water intermittently, and exposes it to thermal shock potential. 
Pipeline failures can be categorized as follows:

1. Thermal or mechanical shocking of the Transite pipe causing wall fracture (generally longitudinal cracks), See Fig. 3

2. Use of improper Dresser couplings (steel-to-Transite couplings) which could move under thermal cycling, resulting in ratcheting and ultimately detaching itself from the Transite pipes,

3. Installation of low temperature gaskets in the Dresser couplings.

4. Rolling the gaskets when replacing a broken section allowing the coupling to leak.

5. Unknown reasons for failure.

Appendix A chronologically lists the failures and the apparent reasons for the failures. The first failure occurred when the mud pumps from the drill rig accidentally, but briefly, injected cold water into the still hot Transite line near site: 2. (See Fig. 4) The failure could have been caused by a mechanical shock, such as from a pressure transient, the thermal shock or both. The magnitude of the pressure transient is unknown. The thermal shock potential is known, however, from thermocouple measurements made on the pipe and in the soil. The pipeline will cool very, very slowly from merely natural conduction, taking about one week to cool to within $25^{\circ} \mathrm{F}$ of the outside air temperature. Therefore, the procedure has been to slowly cool the inlet water by bleeding in cold water, if a change from hot to cold water pumping is demanded over a short period of time.

A problem not directly related to the durability of asbestoscement pipe, involved the ratcheting and ultimate separation of the pipe from the steel end pieces, the joint known as a Dresser coupling. Improved design has eliminated this problem. See fig. 5.

The other fractures that have occurred in the pipe are be lieved to be the result of thermal shocks, but the possibility of one or more being the result of mechanical shocking cannot be excluded. The most likely cause of mechanical shock during operation is bel ieved to be the result of "water hammer." Air or steam bubbles, collapsing or moving past a high spot in the line could possibly result in a significant change in momentum of the flowing water, giving an impulse to the pipe wall. The current procedures for operating the pipeline are designed to minimize the possibilities of both thermal and impulse fractures. 

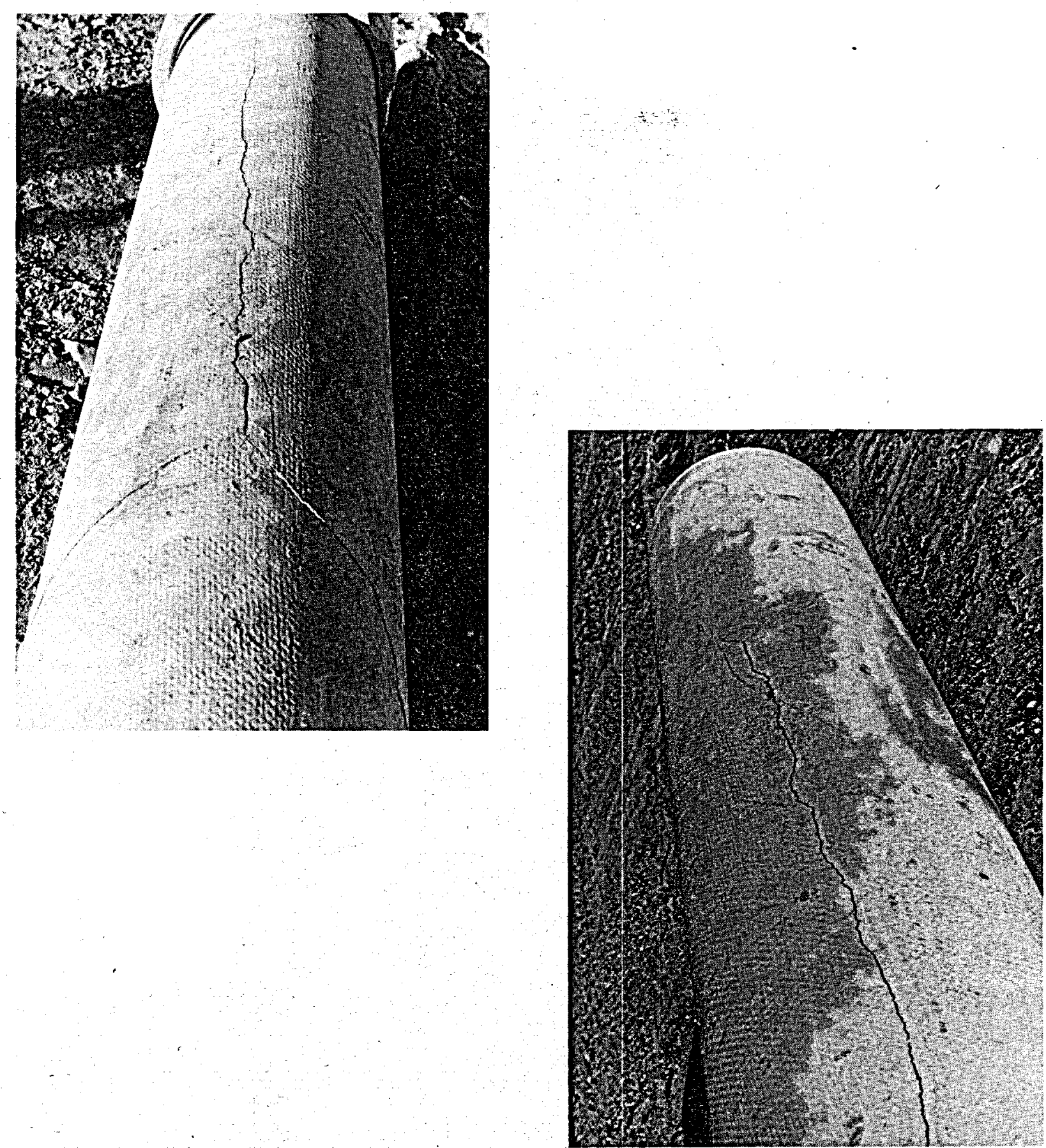

Fig, 3 Close-up pictures of longitudinal fractures in pipeline, probably the result of thermal shock or water hammer mechanical shock 

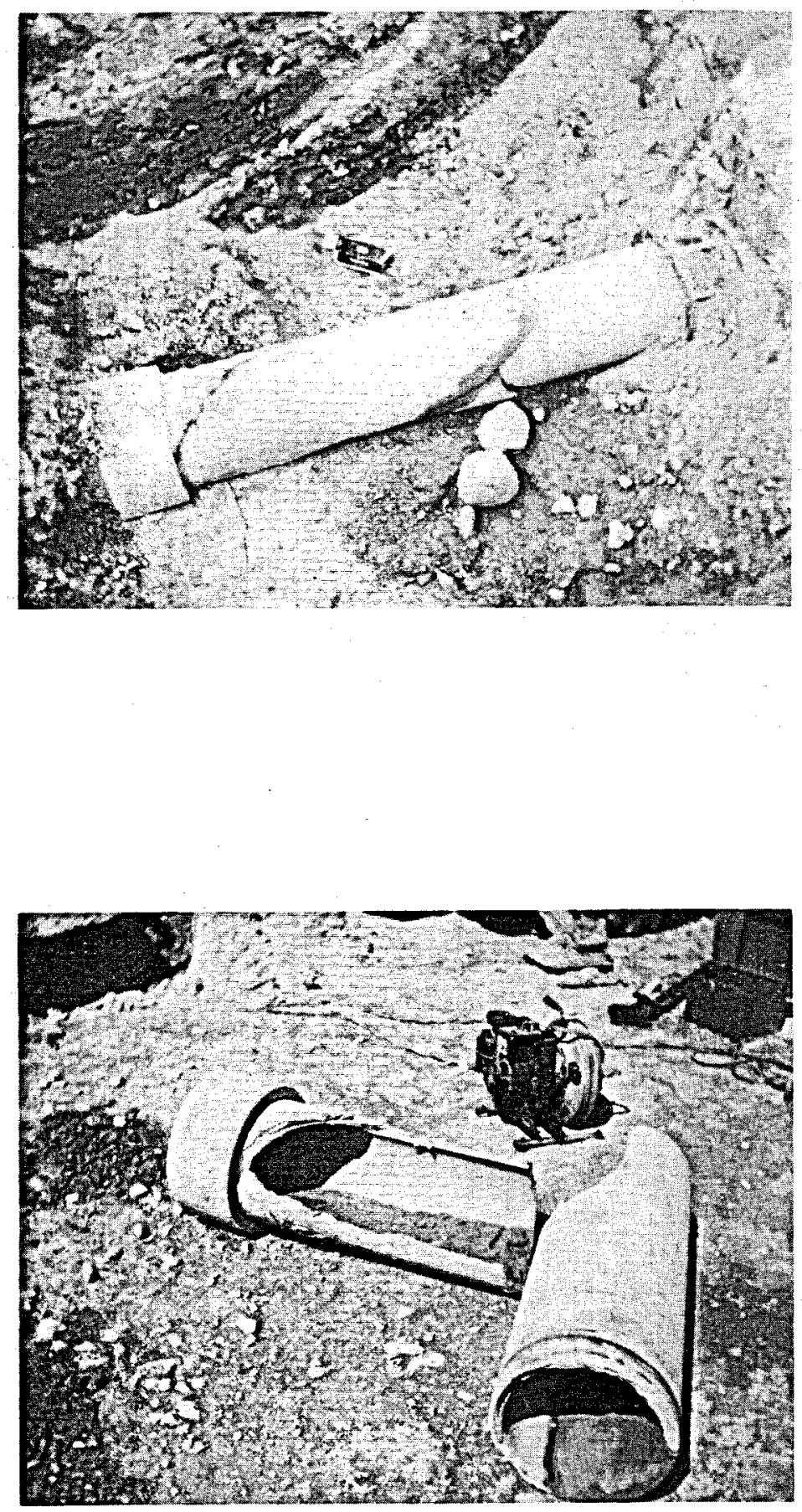

Fig. 4 Transite line failure at site No. 2 when cold water was inadvertently pumped into hot line by drill rig mud pumps. 
Cutting, forming and handling tools have been purchased for use in preparing and installing individual pipe sections. Prior to use of this equipment, three or more pipe sections had to be uncovered and lifted to remove one section. Replacing the section caused the gasket rolling indicated in item 4 above. A pump has been installed to start a small flow of cool water into the line to temperature condition the line. Operating procedures have been established to prevent further thermal shock. Prior to installation of this pump, only the large transfer pump was available for transferring the cool pond water.

The most mysterious failure was an isolated Transite fracture (shown in Figure 6) $2100 \mathrm{ft}$ from site No, 2 at a point where the line was buried $9 \mathrm{ft}$ deep. It consisted of a $6 \mathrm{ft}$ section fracturing longitudinally about $4 \mathrm{ft}$ between collars. The failure did not occur during significant temperature changes, but followed a brief 4 hour termination of hot water flow. The initial fracture could have occurred several weeks previously and only gradually enlarged until it was detectable. When water flow was restarted, it was only $55 \mathrm{gal} / \mathrm{min}$, less than $0.2 \mathrm{ft} / \mathrm{sec}$. This low velocity is unlikely to result in significant water hammer. Hence the reason for the failure is unknown. It could have been any one of a number of reasons such as defective pipe, improper installation, improper handling, and unusual drainage in the area resulting in externally induced thermal shock ( $i, e$, , cooled off in the 4 hour shutdown, then shocked with hot water). 


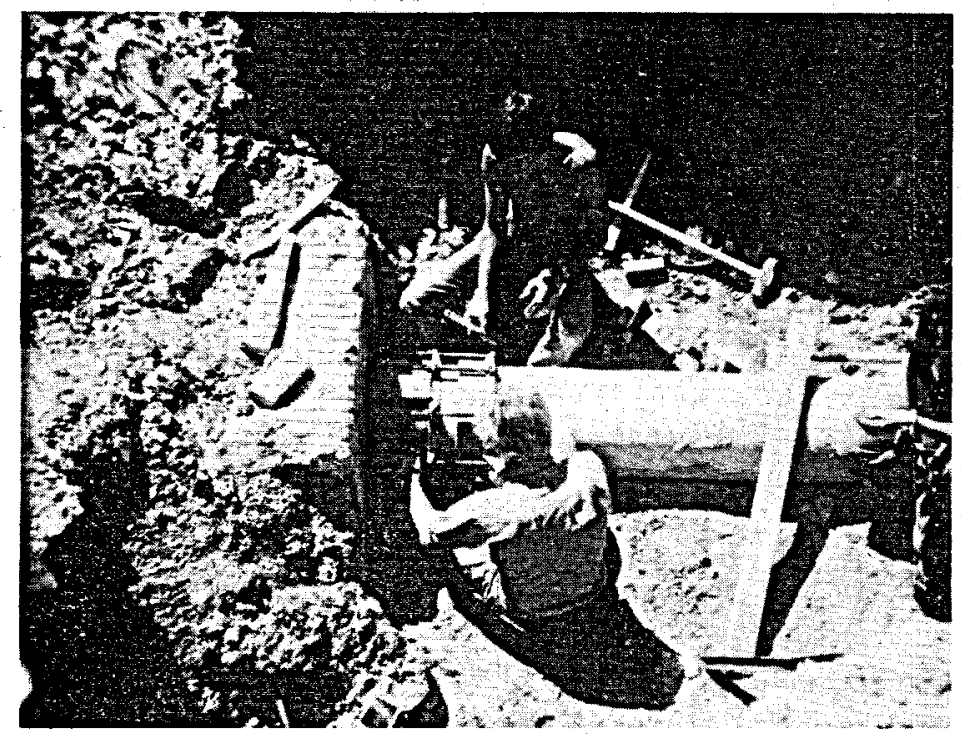

Fig. 5 Blocking Dresser coupling so that thermal cycling could not cause it to move and leak.

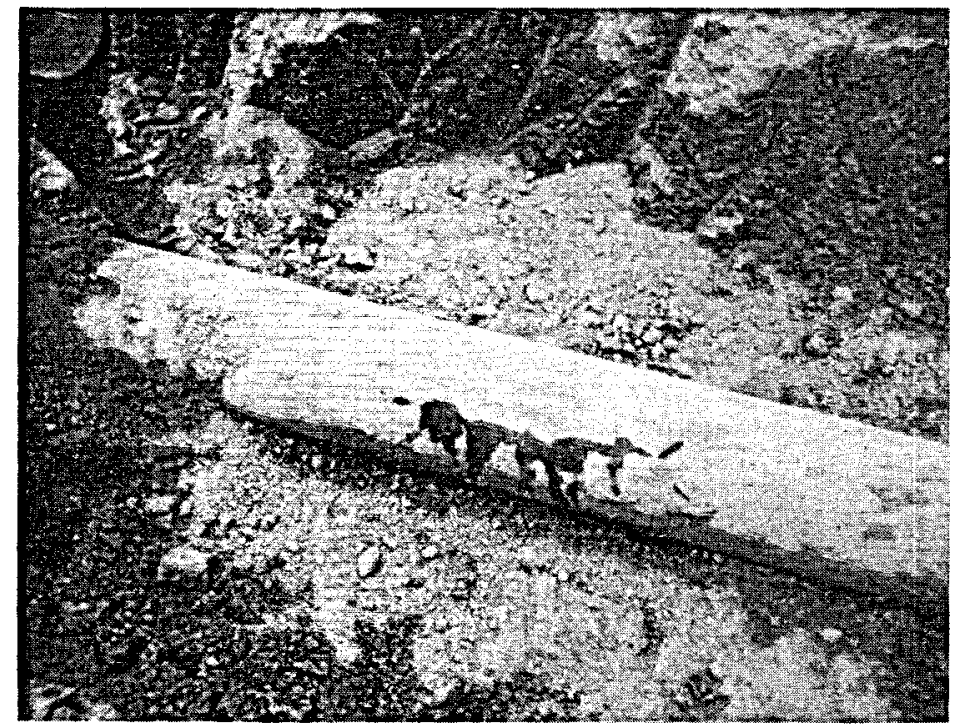

Fig. 6 Fractured line midway between sites, Reason for failure is unknown. 


\section{GENERAL RECOMMENDATIONS FOR ASBESTOS-CEMENT PIPELINES}

From the operating experience gained from this $4000 \mathrm{ft}$ Transite line over the past year, the project office feels that Transite pipe, properly installed by an experienced contractor and used in a proper manner is still the right pipeline material for our temperatures, pressure, and salinity.

For future pipelines at Raft River, the following recommendations should be followed. These do not necessarily differ from those used on the RRGE-1 to RRGE-2 pipeline, but are included in totality for reference purposes,

1. The Transite be installed over a carefully prepared trench bottom with any rocky material covered with sand.

2. The Transite be inspected for damage prior to covering it with insulation and installing it in the trench.

3. The Transite be insulated with 1 to 2 -inches of poly = urethane, sprayed in place after installation, which will thermally insulate and cushion the pipe, and reduce the likelihood of externally induced thermal shocks. (See Section VIII for details on heat loss.)

4. The contractor show previous experience or adequate understanding for installing Transite pipelines.

5. The backfill be free from rocks larger than 1-inch diameter.

6. An EG\&G inspector or field representative be on-site anytime Transite is being installed, tested, and backfilled.

7. Transite line be operated in accordance with appropriate written operating procedures, which generally will require monitoring thermocouples on the pipe.

8. Inspection and verification that all seals used in the line are designed for designated operating temperature.

9. Correct steel-to-Transite couplings recommended by Transite manufacturer be utilized.

10. Pipeline be buried at a shallower depth of approximately 30-inches.

11. Verification should be made of the correct pipe penetration into the collars so that "designed-in" expansion is not inhibited.

12. Crossings of irrigation ditches and streams should be with an "overpass" if possible, to minimize water seepage into the soil around the pipe. 


\section{HEAT LOSS FROM BURIED TRANSITE PIPE}

Heat loss from the pipeline is rather critical when attempting to use these moderate temperature waters for generating electricity. For instance, given a fixed size of heat exchangers and condensers, and geothermal input at $290^{\circ} \mathrm{F}$, each 1 oss of $1^{\circ} \mathrm{F}$ costs nearly $1 \%$ in power output from a turbine. Balancing such a loss is the cost of a pipeline, For initial considerations, the following table lists the approximate cost allocations for a buried Transite pipeline, in normal sedimentary top soil and fine gravel conditions.

\section{APPROXIMATE COSTS PER MILE}

\section{IN. BURIED TRANSITE PIPELINE}

Transite pipe, purchase price, including couplings

Excavation and backfill for 30 in, burial* depth

(for 48 in, depth $=\$ 65,000$ )

(for 24 in, depth $=\$ 30,000$ )

Installation of pipe into trench

Insulation - 1 in. sprayed urethane, low flame spread type

(\$1.25/lb material cost, typically

$3 \mathrm{lb} / \mathrm{ft}^{3}$ density. 2 in, thickness

applied is approximately $55 \phi / \mathrm{ft}^{2}$

or $\$ 1.60 / \mathrm{ft}$

Contingency

Approximate Total
$\$ 35,000$

40,000

20,000

al depths quoted for total trench depth to bottom of pipe.

The above analysis indicates minor cost sensitivity to depth of burial. However, if trench depth exceeds nominally $4 \mathrm{ft}$, mechanical shoring of the sidewalls of the trench will be required, adding substantially to the cost. Since a pipel ine should be laid as uniformly straight (or level) as possible, to minimize the strain on the gasket couplings, an uneven terrain may require shoring in certain sections, none in others. A 30-inch burial depth leaves nearly $2 \mathrm{ft}$ contingency for terrain unevenness before shoring is required. The following analyses assume a 2 to $3 \mathrm{ft}$ burial depth. 
Material

Transite Pipe

Water

Dry Soil and Sand

Sand and Gravel Mix

Styrofoam Beads

Rock Wool Fibre

Fibreglas

Urethane Foam (3 $1 \mathrm{~b} / \mathrm{ft}^{2}$ )

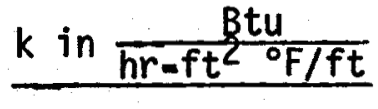

0.49

0.38

0.18

0.9

Dry

0.020

Service Temp $180^{\circ} \mathrm{F}$

0.026

Dry

0.033

Dry

0,012
Comments

Wet 


\section{Resistance in $\left(\frac{\mathrm{Btu}}{\mathrm{hr}^{\mathrm{C} F} / \mathrm{ft}}\right)^{-1} * *$}

0.059

Transite pipe, wet, $10 \mathrm{in}$, diameter

by 1 in thick wall

Urethane foam, $1 \mathrm{in,} \mathrm{thick}$

2.0

Wet soil $24 \mathrm{in}$. depth to pipe centerline

1.11

$k=0.330 \mathrm{in}$. depth to pipe centerline

1.22

36 in. depth to pipe centerline
Dry soil $30 \mathrm{in}$. depth to pipe centerline $\quad 2.0$

Dry soil. 60 in. depth to pipe centerline $\quad 2.65$

Wet soil $60 \mathrm{in}$. depth to pipe centerline $\quad 1.59$ for the "half space" soil situation, all conduction upward

$$
=\frac{\ln R o / R i}{2 \pi K} \quad \begin{aligned}
& \text { for full radial conduction, } \\
& \text { such as pipe wall and insulation }
\end{aligned}
$$

The use of urethane insulation, 1-inch thick, for pipe buried $3 \mathrm{ft}$ will effectively reduce the heat loss by a factor of at least two, even more for conditions of wet soil. One inch of urethane is as effective an insulator as $5 \mathrm{ft}$ of typical soil. Whether more than 1 -inch thickness of urethane is appropriate should depend on a cost/benefit ratio, of lost power from the electric generating plant due to the reduced temperature. For purposes of anal.ysis, a resistance of

$$
R=1.0\left(\frac{\mathrm{Btu}}{\mathrm{hr} \mathrm{r}^{\circ} \mathrm{F} / \mathrm{ft}}\right)^{-1}
$$

and

1. a temperature difference of $250^{\circ} \mathrm{F}$ between the fluid in the pipe and the outside air temperature.

2. a flow of $1000_{5}$ gallons/minute through the 10 in, Transite pipe $\left(4.8 \times 10^{5} \mathrm{lb} / \mathrm{hr}\right)$. 
results in the following

Heat loss per mile of pipeline $=1.32 \times 10^{6} \mathrm{Btu} / \mathrm{hr}$ (equivalent to $48 \mathrm{~kW}$ of electricity at $12-1 / 2 \%$ conversion efficiency)

Fluid temperature loss per mile of pipeline $-2.75^{\circ} \mathrm{F}$

The use of urethane foam, 1-inch thick, gives a thermal resistance for the pipeline exceeding 2, and thus temperature loses are less than half this amount. The addition of an extra inch of urethane thickness would reduce the net power loss by about $16 \mathrm{~kW}$, equivalent to $\$ 2900$ worth of electricity/year at a bus bar rating of 25 mills/kW-hr. Thus, 2-inches of urethane can be justified on a cost-benefit basis for most pipelines, The value of the lost energy in direct heat (non-electric) applications is generally less, and more difficult to assign a precise value, because of varying plant capacity factors and generally lower price assigned to thermal energy. In that case, 1-inch of urethane may be the optimum thickness for cost effectiveness.

Experience with the present pipeline between wells No, 1 and No, 2 for heat loss and soil temperature measurements is summarized in Appendix B. Measured heat loss compares closely with the above listed thermal conductivities and resistances. The results indicate that the average thermal resistance for the pipeline, buried a minimum of $5 \mathrm{ft}$, is 1.9 (Btu/hr-ft- $\left.{ }^{\circ} \mathrm{F}\right)-1(+5 \%,-40 \%)$ for each foot of pipe. This result. corresponds to an average thermal conductivity for the soil of $0,25 \mathrm{Btu} / \mathrm{hr}-\mathrm{ft}-{ }^{\circ} \mathrm{F}$ $(+40 \%,-5 \%)$. 
Transite is the appropriate cost effective pipeline material for the temperature, pressure, and flows encountered at the Raft River Geothermal Project. Most of the problems encountered to date with Transite can be circumvented by: 1) rigid inspection during installation; 2) correct steel-to-Transite couplings; and 3) use of appropriate operating procedures to mitigate the severity of shocks,

The only alternative to Transite would be steel pipe, either above or below the ground. In either case, it is extremely expensive with its vertical or horizontal expansion loops. Placing steel above the ground is probably the more common method. However, it causes problems, mostly esthetic, but from a safety standpoint, it can be damaged, sabotoged or run into by vehicles, etc. The unsightliness of the line and expansion loops snaking across the landscape does not appeal to the esthetic beauty of a power plant.

The cost effective characteristic is significant. Present costs of a Transite line are about $\$ 110,000 /$ mile, while a steel line will cost nominally twice as much. This includes the cost of urethane foam insulation, between 1 and 2 -inches thick, and results in a pipeline with loses, less than the equivalent of $20 \mathrm{~kW}$ (per mile) of electric power production from the power plant,

For geothermal fluids of higher salinity, the smooth wall asbestoscement and their resistances to pitting corrosion should make this pipeline even more desirable compared to steel. 
APPENDIX A

$$
\frac{\text { Pipeline Failures (From Raft River Log Book) }}{\text { (* designates failures in cement-asbestos) }}
$$

12-7-75 12-inch Transite line completed.

1-16-76 12-inch Transite leak - Dresser coupling moved toward thrust block allowing 0-ring to slip off Transite pipe. Recentered coupling.

1-28-76 Dresser coupling leaking on cold-water pumping; recentered coupling between 10-inch steel and 12-inch Transite,

12-inch Transite pipe ruptured at No, 2 while flowing from No, 1 to No, 2 An inadvertent slug of cold water was pumped into the hot line from the drill rig.

3-29-76 Ruptured section replaced (delayed because of drill rig moving off site).

6-18-76 Valley Utilities replaced gaskets on both Dresser couplings with correct materials.

7-2-76 Transite leak at No. 2 - collar shifted - recentered collar.

7-4-76 Transite leak at No, 2 - collar shifted - recentered collar.

7-7-76 Dresser coupling blow-off at No, 1 - recentered collar.

* 7-8-76

Transite pipe section fractured due to thermal shock. Broken piece replaced and collar recentered near site No. 1.

7-9-76 Replaced gaskets in Dresser coupling at No, 1 with used rubber gaskets.

* 9-25-76 Transite broke - about four joints from site No, 1 due to thermal shock.

10-1-76 Transite broken section replaced; second broken section found.

10-2-76 Second section replaced.

10-8-76 Broken gasket on Dresser coupling at No, 1 site.

10-9-76 Gasket replaced.

10-15-76 Dresser coupling leak at No, 2 ,

10-22-76 Replaced gasket at No, 2 with packing,

10-27-76 Dresser coupling leaking again at No, 2 - continuing, correct couplings on order for its repair.

* 11-11-76 Transite broke mid-distance between No, 1 and No, 2 with cause unknown. 
11-13-76 Transite section replaced - still leaking.

11-15-76 Air bleed valve in next section broken - leaking; also joints leaking from rolled gaskets.

11-17-76 Rolled gaskets still leaking.

11-18-76 Replaced gaskets. 
The pipeline was instrumented, as shown in Figure $B-1$, in a region of typical Raft River region soil, with thermocouples to measure the temperature gradient in the soil. The fluid temperature loss from one end to the other of the pipeline was also measured. These measurements began a week after cold winter weather set in. The results of these measurements are shown in Figure B-2. The pipeline carried $235 \mathrm{gpm}$ for the first 2-1/2 weeks, but equilibrium temperature conditions had not been reached when the flow was reduced to $65 \mathrm{gpm}$. During the next 6 weeks, the temperatures stabilized, allowing an estimate of heat loss to be made and average soil resistance/conductivity computed. At that time temperature drop of the fluid from one end to the other end (4000 ft away) on the pipeline was $13^{\circ}$. For $65 \mathrm{gpm}$ flow, this gives a loss of $405,000 \mathrm{Btu} / \mathrm{hr}$, leading to the following result, in $\left(B t u / h r-{ }^{\circ} F\right)^{-1}$ for $R$.

$$
\begin{aligned}
& \text { Total R/ft of pipeline }=1.97 \\
& R \text { for soil/ft of pipeline }=1,92 \\
& k_{\text {avg }} \text { for soil }=0.25 \frac{B t_{y}}{h r-\mathrm{ft}^{2}-\mathrm{F} / \mathrm{ft}}
\end{aligned}
$$

The earlier results from the higher flow rates, approaching but not yet reaching equilibrium temperatures, gave conductivities substantially higher. The longer term results, however, agree closely with partially wet, sandy soil conductivities, and hence appear to be reasonable values to use in future design. 


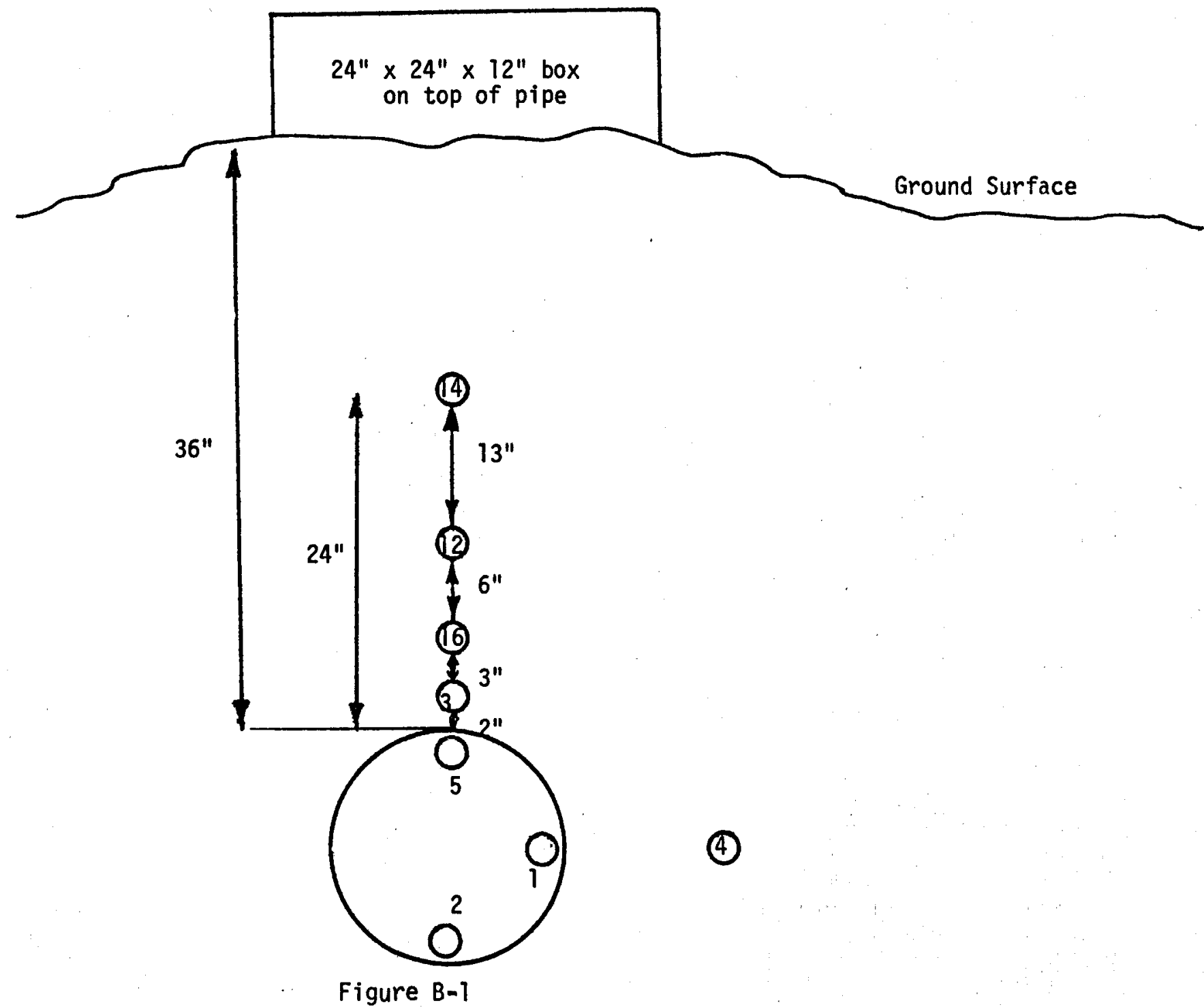

Physical location of monitoring thermocouples placed in soil around 12-inch dia Transite pipeline, Measurement location was near the RRGE No, 1 security force. 


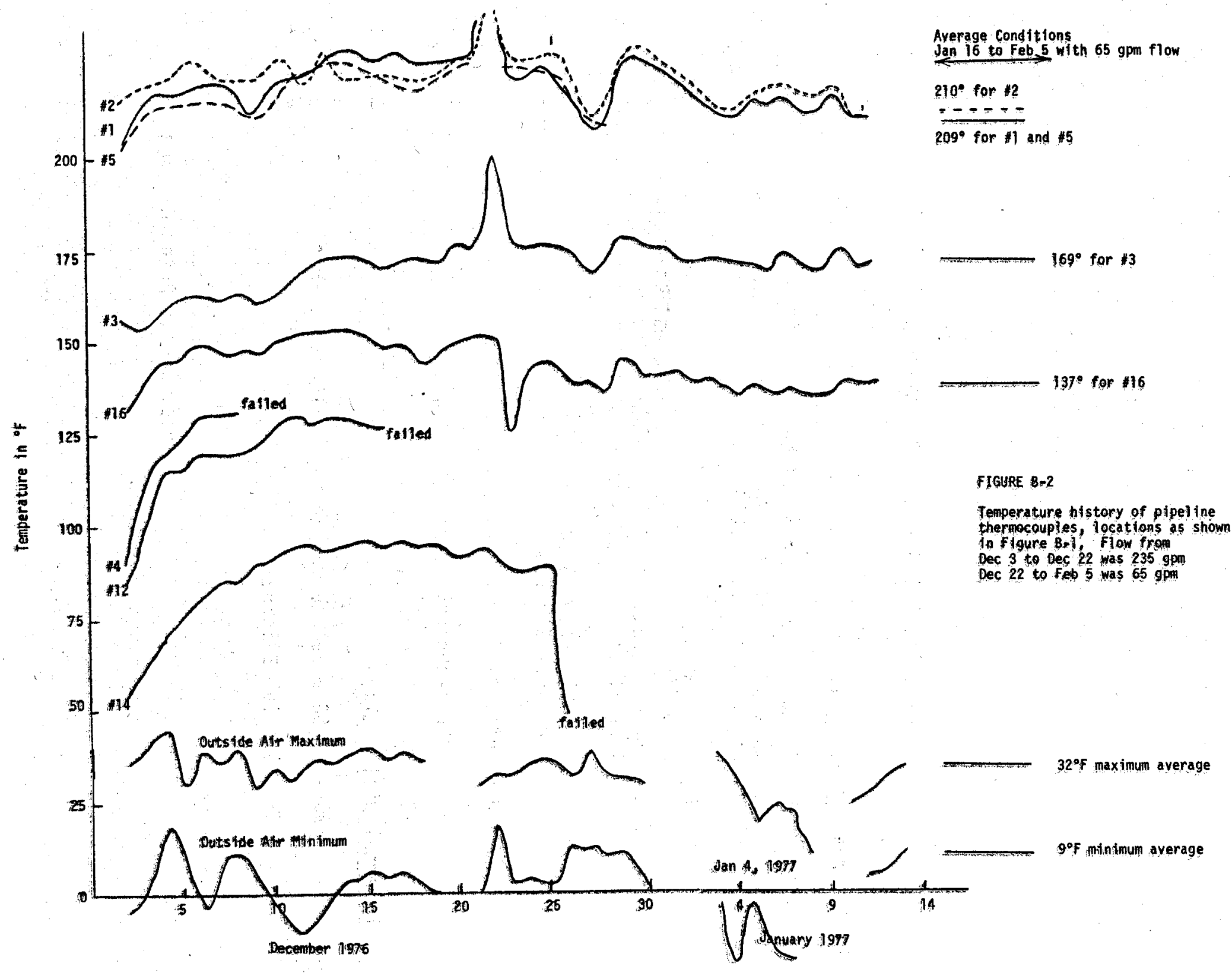




\section{DISTRIBUTION RECORD FOR TREE-1114}

\section{Internal Distribution}

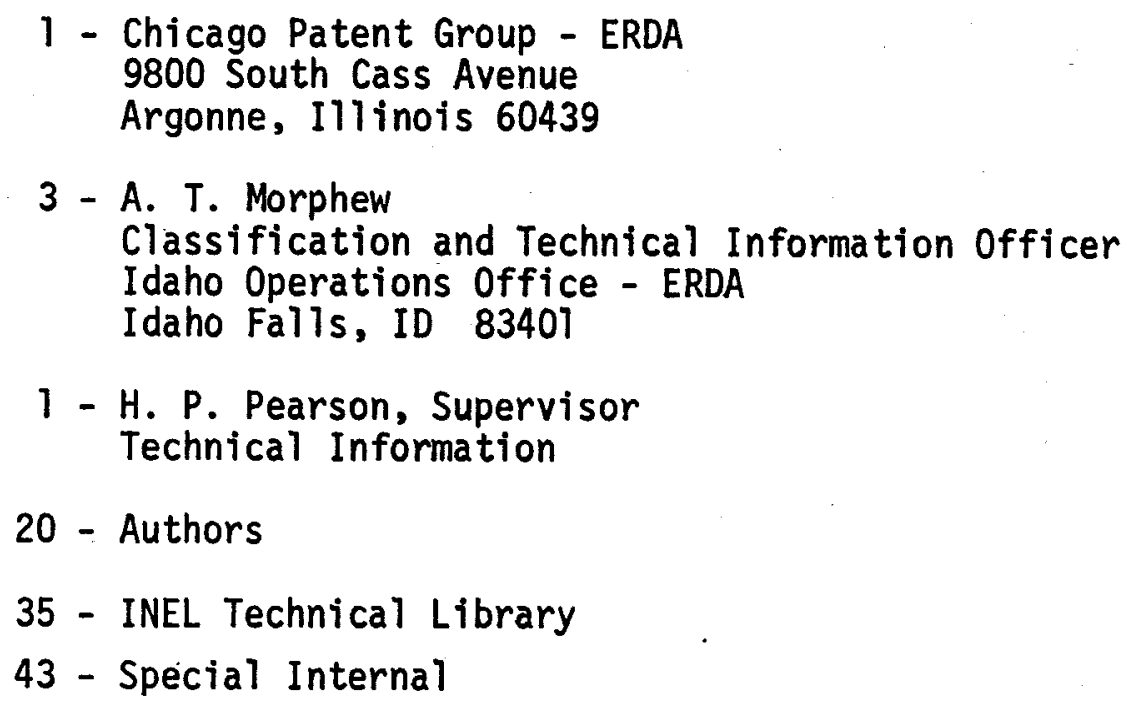

External Distribution

$$
\begin{aligned}
& 390 \text { - UC-66 - Geothermal Energy - TID-4500, R65 } \\
& 75 \text { - Special External }
\end{aligned}
$$

